\title{
PROBLEMA
}

Anuario de Filosofia

\section{METAETHICS FOR EVERYONE}

\author{
Andrew REISNER
}

\section{Resumen:}

En palabras de Dworkin "el escepticismo moral es una concepción moral"; esto en contraste con la idea más popular de que el verdadero reto para el realismo moral es el escepticismo externo, un escepticismo que proviene de consideraciones no morales sobre la metafisica de la moral. Al igual que otros no comparto las conclusiones más poderosas de Dworkin acerca de la viabilidad del escepticismo externo; sin embargo, considero que su crítica de un "escepticismo equivocado" aporta una muy útil enmienda a los proyectos de metaética más tradicionales. Mi objetivo en este ensayo es separar las diferencias entre la perspectiva de Dworkin y las perspectivas tradicionales, para al final concluir que el trabajo de Dworkin, en Justice for Hedgehogs, contribuye a una metaética para todos.

\section{Palabras clave:}

Metaética, metafísica moral, realismo, objetividad, escepticismo, Dworkin, Ronald.

\begin{abstract}
:
As Dworkin puts it: moral scepticism is a moral view. This is in contrast to the more popular idea that the real challenge for moral realism is external scepticism, scepticism which arises because of non-moral considerations about the metaphysics of morality. I, too, do not concur with Dworkin's strongest conclusions about the viability of external scepticism. But, I think his criticism of error scepticism offers a much needed corrective to more tra-
\end{abstract}




\section{ANDREW REISNER}

ditional metaethical projects. My aim in this paper is to split the difference between Dworkin's view and more traditional views, concluding that Dworkin's work in Justice for Hedgehogs contributes to metaethics for everyone.

\section{Keywords:}

Metaethics, Metaphysics of Morality, Realism, Objectivity, Scepticism, Dworkin, Ronald. 
Summary: Introduction. I. How to Become an Error Sceptic. II. No Morons: The Argument from Queerness and Dworkin's Objections to It. III. Moral Properties on the Cheap. IV. Refocusing on Concepts. V. Conclusion. VI. References.

\section{INTRODUCTION}

I want to take up one of Ronald Dworkin's many very interesting ideas from Justice for Hedgehogs. It is the idea that the only intelligible scepticism about morality is in an important sense internal to morality. To paraphrase Dworkin: moral scepticism is a moral view. ${ }^{1}$ This is in contrast to the more popular idea that the real challenge for moral realism is external scepticism, scepticism which arises because of non-moral considerations about the metaphysics of morality. In this paper, I am particularly interested in what Dworkin calls 'error scepticism'. Error scepticism is the view that morality (moral thought, moral discourse, moral metaphysics) is altogether mistaken, because for non-moral metaphysical reasons we should doubt that there are any genuine moral properties.

Many philosophers raised on a diet of more traditional metaethics will find Dworkin's rejection of the coherence of external, and particularly error, scepticism improbable at best. I, too, do not concur with Dworkin's strongest conclusions about the viability of external scepticism. But, I think his criticism of error scepticism offers a much needed corrective to more traditional metaethical projects. My aim in this paper is to split the difference between Dworkin's view and more traditional views. No doubt this will leave neither Dworkin nor the traditionalists very satisfied. So it goes with the wisdom of Solomon.

There has been of late some important work in metaethics that treats the metaphysics of moral properties as being

1 Dworkin (2011). The original phrasing is '...external skepticism is itself a moral position...' 
of lesser importance than moral judgement and moral speech. ${ }^{2}$ This is not exactly Dworkin's line, but some of the work in this vein has interesting resonances with it. ${ }^{3}$ I would like to tentatively join the crowd who thinks metaphysical problems are not at the fore of central issues in metaethics, but I would like to do so in a realist and non-deflationary way. Dworkin's criticisms of error scepticism can help us to see that moral properties, while not deflated, are cheap, especially on views about properties that are naturalistic.

I can give only a sketch of why moral properties may turn out not to be ontologically problematic. But, this sketch will help elucidate why error scepticism, though coherent, is more likely than not to be essentially uninteresting. Once one sees the general lack of interest in external scepticism, there is a good case for moving closer to Dworkin's approach to metaethics by focusing on concepts.

\section{How to Become AN ERRor Sceptic}

Error scepticism as a view has a long history in analytic philosophy. It is instructive to look at how it came to gain a foothold in our contemporary thought.

Metaethics was a central topic of interest during the early years of analytic philosophy, ${ }^{4}$ not least of all because of $\mathrm{G}$. E. Moore's important work, Principia Ethica. ${ }^{5}$ Principia Ethica covers a remarkably wide spectrum of moral theory, including metaethics, axiology, and normative theory. Perhaps its most influential legacy is the open question argument.

The open question argument was used in service of a claim about the property, good. That claim is that good is a non-

2 See Scanlon (2009) and Skorupski (1999). Indeed, Skorupski is an anti-realist about moral properties.

3 Dworkin and Skorupski both draw on Kantian ways of understanding our capacity for moral judgement to support the truth-aptness of moral claims.

4 A good sense of this significance may be seen by consulting the table of contents for Soames (2005).

5 Moore (1903). 
natural, unanalysable property. Moore supposes that for any $\mathrm{F}$ in a question of the following form:

$\mathrm{x}$ is $\mathrm{F}$, but is it good?

the question may be considered open. A question is open if it is intelligible in the sense of not being a tautology, or perhaps an obvious tautology. If there were a trivial equivalence between $\mathrm{F}$ and good, then the question would have the sound of asking ' $x$ is F, but is it F?'.

Moore draws two conclusions from the open question argument. The first is that good is a non-natural property. Were it a natural property, then the question should be closed when the appropriate natural predicate is substituted for F, but this never seems to happen. The other conclusion is that good is unanalysable. If it were analysable, we should be able to provide a satisfactory (possibly complex) predicate, natural or non-natural, that would close the question.

Setting aside discussion of what the open question argument in fact shows, ${ }^{6}$ it is worth noting that from an historical point of view, it was impressively persuasive, although perhaps not with the results that Moore would have either anticipated or liked. Perhaps the most important effect of the open question argument for much of the 20th century was to bolster moral anti-realism.

This surprising outcome for an argument intended to support a particular kind of moral realism occurred as a result of developments that took place in the roughly thirty years following the publication of Principia Ethica. With the rise of logical positivism and in particular radical empiricism, a new and deflationary approach to metaphysics took hold. For the history of metaethics, the important figure was A. J. Ayer. ${ }^{7}$

6 Just what the open question argument shows is a matter of some controversy. See Ball (1988) for a good general discussion.

7 Ayer (1936). Another influential figure was C. L. Stevenson. See in particular Stevenson (1937). 
Ayer famously claimed that synthetic propositions only have descriptive meaning if they are empirically verifiable. ${ }^{8}$ Having found the open question argument convincing, he took good to be a non-natural, and therefore empirically unverifiable property. This makes propositions or sentences in which good (or 'good') figures descriptively meaningless. As a consequence, moral claims (moral sentences or moral beliefs) should be interpreted as having a non-descriptive meaning: emotive meaning. ${ }^{9}$ In effect, saying that ' $\mathrm{X}$ is good' is just a way of saying 'Hooray for $x$ ', where 'hooray' is understood to indicate a pro-attitude towards $\mathrm{x}$.

Radical empiricism is not a metaphysically heavily laden view; Ayer expresses his worries in terms of meaning rather than in terms of properties or states of affairs. Nonetheless, as a philosophical outlook, it marks the beginning of a lasting concern about the commensurability of moral realism and respectable metaphysical naturalism. The connection of naturalistic worries about the metaphysics of moral properties to verificationism is not only historical, but to a degree philosophical. Verifiability for the most part ceased to be a worry for semantics, but its scientistic overtones were readily assimilated into a broader programme of naturalistic metaphysics in the 20th century. As long as the open question argument continued to be persuasive, the prospects for offering a naturalistically credible realist metaethics looked dim. Metaphysical naturalism in this way served as an important grounds for error scepticism.

The force of the open question argument has been called into serious question by more recent thinking about the distinction between the necessary and the a priori. ${ }^{10}$ The gist of much of the current thinking is that to the extent the open question argument shows anything at all, it shows

8 Ayer (1936).

9 'Descriptive meaning' and 'emotive meaning' are terms coined by Stevenson. They are convenient to use in this context for reasons of clarity. Ayer speaks of the emotive use of ethical terms.

10 The impact of this thinking has been most keenly felt in the wake of Kripke's (1980) Naming and Necessity. 
that none of the putative natural identities for good are a priori, but this leaves room for there to be a naturalistic identity for good that can be known or discovered a posteriori.

While the possibility of finding an a posteriori identity for good has helped to promote new avenues for metaethical realists, ${ }^{11}$ a second line of naturalistically motivated scepticism remains intact and influential. It is this line that is one of the principal targets of Dworkin's arguments in JFH. ${ }^{12}$

\section{No Morons: The Argument From QueERnesS AND DWORKIN'S OBJECTIONS TO IT}

In 1977, J. L. Mackie published a book, Ethics: Inventing Right and Wrong, which is in many ways the modern starting point for the metaethical debates leading up to the current day. He offers a line of argument for scepticism about the existence of moral properties that runs independently of the open question argument, but the argument remains motivated by a thoroughgoing metaphysical naturalism. In fact, Mackie offers two distinct types of argument: the argument from queerness and the argument from disagreement. ${ }^{13}$ It is the former that is of importance for this paper.

There are, in fact, two arguments from queerness. One is the argument from metaphysical queerness, the other from epistemological queerness. The metaphysical argument from queerness is the one that most concerns Dworkin and will be the focus here. According to Mackie, the kinds of properties about the existence of which we are most confident are those that are given to us by science and perhaps ordinary parlance about the natural and artificial world. We thus countenance a wide range of properties from being a

11 See Boyd (1988) and Railton (1986) for post Naming and Necessity examples.

12 Dworkin (2011), pp. $23 \mathrm{ff}$.

13 Mackie began developing these influential lines of argument some time earlier in Mackie (1946), but they did not gain broad currency until the publication of Mackie (1977). 
quark and having a spin to being an automobile and having a high top speed. All these properties are supposed to be similar in that they seem to accord with our basic scientific understanding of the universe. It is also important for Mackie that real properties are primary qualities. Secondary qualities, as he understands them (essentially as response dependent properties), are not in fact real properties.

Moral properties are supposed to be different from the scientifically respectable ones. They do not have the hallmarks of the kinds of properties that science normally postulates; the physical sciences are not in the business of discussing normative properties in general. Ordinary objects and properties- like my desk, my car, and the properties of being a desk or being a car- are also ontologically respectable, because one way or another ordinary objects are composed of things science talks about: atoms, molecules, quarks, electrons, etc. To accommodate them in our ontology, we do not need to go much beyond what science posits.

The same supposedly cannot be said for moral properties, which have in Mackie's view some very odd features. One is that they are magnetic. Moral properties have the power to attract individuals towards certain kinds of behaviours or states of affairs and to repel them from others. The second is that they are normative. They have some special guidingness which intellectually suitable people recognise. One can see that they are guiding or to be followed, possibly in a way that is independent of one's motivation to follow them.

Moral properties are therefore queer. They are not like the properties in our ontology in which we have the greatest confidence: they are not like what science gives to us. Further, they are hard to find. ${ }^{14}$ We can ostend a great many natural properties. I can show you that diamonds are harder than quartz by scratching a quartz crystal with a di-

14 One can see a certain connection to verificationism in this line of thought. 
amond. I can show you that a ceramic mug is brittle by dropping it on the floor with the result that it shatters. But, I cannot show you the wrongness of an action or the badness of a state of affairs in anything like the same way. The queerness of moral properties, according to Mackie, should lead us to doubt their existence, although it does not absolutely rule out the possibility that they may exist.

In various different ways, much of the literature following Mackie agreed that he had set out the terms of the challenge to moral realism correctly. Responses sought to defend realism by taking up the challenge of showing that secondary qualities are, in fact, real and that values are secondary qualities; 15 arguing that Mackie's metaphysical analysis recommends abandoning a classic truth-functional understanding of moral sentences and moral judgements; 16 or by trying to find a suitable set of primary qualities that meets Mackie's criteria. ${ }^{17}$

Despite some efforts to avoid the problem, Mackie's queerness objection looms large in current thinking about moral properties. The question of how morality, and perhaps normativity more generally, fit into a naturalistic ontology is supposed to be one of the important outstanding questions of metaethical theory. For many naturalists, the most satisfactory answer is ontological scepticism about moral properties: what we know about metaphysics suggests that morality has no place in our ontology.

Quite rightly, Dworkin suggests that there is something odd about this picture. ${ }^{18}$ One might sum up a number of his claims in the following way: Just what is it that we are supposed to be doing when we ask about whether it is wrong to kill? We are asking what are the relevant moral

15 McDowell (1985).

16 Blackburn (1984).

17 Railton (1986). Indeed, it is a little noticed feature of Railton's influential paper that he is careful to link his needs/desire account to a primary quality view in metaphysics. Later writers would also return to a primary quality of moral properties. See Jackson (2000).

18 See Dworkin (2011), especially ch. 3. 
considerations. These might include that killing someone robs him of an opportunity to carry out his life projects, that killing someone denies to him various future goods, and so on. These are moral considerations. We are not tempted to make certain kinds of non-moral inquiries. For example, we do not pull out a special kind of scope and look for morons, moral particles that attach themselves to the objects of moral evaluation. To think that what makes killing right or wrong, or the suffering of the masses good or bad, is a matter of some metaphysically basic moral particle seems difficult even to understand. ${ }^{19}$ Contrast this with how we might go about discovering whether a salt crystal has such-and-such a structure or whether snow is, in fact, white. In these non-normative cases, while we may employ arguments, we consider the source of truth makers to be features of nature herself.

To put Dworkin's point a different way, we expect moral explanations for moral facts. When asking whether it is right to save a life, when there is no danger to one's own from doing so, one is usually expecting a moral case to be made, not a naturalistic one. There is no need to go hunting for morons to explain the rightness (or lack thereof) of saving a life, the permissibility of donating either to one worthy cause or to a different one, or the wrongness of inflicting unnecessary suffering on innocents. Explanations of the truth of moral claims come in the form of moral explanations. ${ }^{20}$ But what of truth makers for moral claims?

Dworkin thinks that there are no truth makers for moral claims, although moral claims (moral judgements and sentences expressing moral propositions) are truth-apt, and in

19 Mackie presumably would offer different terminology and does not discuss moral particles directly.

20 See Dworkin (2011), pp. 29-32. Dworkin takes the lesson of Hume's arguments about the is/ought gap not to be that we should be sceptical about moral truths, but rather that we should expect moral truths to be supported by moral, rather than non-moral, arguments. 
this view he is not alone. ${ }^{21}$ His particular route towards a truth maker free theory of moral truth is both complicated and controversial. I shall not take it up here. Instead, I would like to develop Dworkin's idea that there is something peculiar about the idea of hunting for morons to learn moral truths, and that issues in metaphysics external, in his sense, to morality are unlikely to tell us much about what moral truths there are, or whether there are indeed any moral truths. My reasons for thinking that external or status scepticism is of little interest or concern are different from his. Little is revisionary in what I shall say as regards the basic framework of metaethics as it is currently thought about in the literature. Instead, I shall suggest that moral properties are so innocuous as to be of little use or interest in argumentation about which moral truths there are, or whether there are moral truths at all. In order to do all this, I shall have to go over some metaphysics first.

\section{Moral Properties on the Cheap}

Mackie-inspired worries about moral properties are supposed to be especially trenchant for metaphysical naturalists. In this context it is ontological naturalism, rather than epistemological or methodological naturalism that is of interest. Reductive (ontological) naturalism is the view that there is a privileged set of properties that are natural and that these are the only basic properties. Complex properties can be assembled out of the basic ones, but complex properties requiring non-natural properties as constituents will themselves be considered non-natural.

The privileged class of properties is normally thought to comprise those properties required by the appropriate sci-

21 See Scanlon (2009) and Skorupski (1999) for detailed discussion of ways in which one might get moral truth without truth makers using approaches that deny less of the standard metaethical framework than Dworkin's. 
ences. ${ }^{22}$ Which sciences are appropriate and other problems with understanding the boundaries of the privileged class will be ignored here. What naturalists are after is a respectable group of properties, and respectability is normally thought to be tied in with being invoked by science.

Moral properties are thought to be problematic in part because they are not invoked by the natural sciences. Indeed, perhaps outside of the medical sciences and perhaps some biological sciences, the philosopher's notion of normativity has no place. ${ }^{23}$ Being a robust moral realist appears to require us to accept the existence of spooky non-naturalistic properties which are not adequately respectable for our ontology.

As Dworkin's barbs about morons suggest, there is something odd about this picture. Moral realists rarely take themselves to be in the business of supernatural investigation. ${ }^{24}$ Indeed, it is not clear that thinking that there are real moral properties commits one to an ontology very greatly enriched over the ordinary scientific one. To see why, it will be helpful to observe just how easy it is to identify a moral property with a natural property.

The approach that I shall take here finds its inspiration in Frank Jackson. ${ }^{25}$ The version discussed here differs in important ways from Jackson's, however, and should not be taken as a reading of Jackson's view. ${ }^{26}$

22 That is, the respectable properties are those that are required by, or at least posited by, those sciences that are considered respectable for the purpose of giving us the privileged properties.

23 The notions of health and disease, normal and abnormal, may have normative components to them.

24 Indeed, G. E. Moore, a non-naturalist par excellence, thought the open question argument ruled out not only naturalism about moral properties, but also supernaturalism about them.

25 Jackson (2000).

26 Perhaps the most important difference is that Jackson's way of doing things relies on treating propositions as sets of possible worlds. The equivalent step in the argument here is to treat properties as being co-intensional, in particular as functions from worlds to extensions. The approach I am using is more fine-grained than Jackson's. It is possible, for example, to differentiate propositions expressing dis- 
We begin with three important assumptions:

a) Normative properties globally supervene on natural properties (all minimal physical duplicate worlds are exact normative duplicate worlds).

b) Properties are functions from worlds to extensions.

c) Arbitrarily large conjunctive and disjunctive properties are respectable.

On these assumptions we can (trivially) construct a natural property that is identical to any normative property. This is the procedure. First, we look at the extension of the normative property, say being good, at a world. We then generate a property of being good at that world, the extension of which comprises all the good events in that world.27 To do so, one describes each good event, one-by-one. Each good event with the circumstances under which it occurs will form a (potentially large) conjunction. Each of these conjunctions then serves as a disjunct for a large disjunctive property, one of the disjuncts of which is the conjunction of good events with the circumstances under which those events occur. ${ }^{28}$ When we come to the last disjunct, we close off the disjunction with an and nothing more clause. This disjunctive property will be coextensive with the property of being good at that world. We now move to the next world and repeat the same procedure. Having gone to all the worlds, we now close off the massive disjunction with an and nothing more clause.

This procedure generates a natural property that is necessarily coextensive with the property of good. Because properties are functions from worlds to extensions and cannot be more finely individuated than that (by stipulation),

tinct necessary truths by treating properties as extensional, but it is not possible to do so if propositions are treated as sets of possible worlds.

27 I am using events as a convenient object of evaluation; the extension of good could include actions, states of affairs, material objects, psychological states, and so on.

28 Events are joined with their circumstances of occurrence to accommodate fine-grained varieties of axiological particularism. 
necessary coextension is sufficient for identity. So, we have generated a natural property that is identical to being good.

There are more ways than one to achieve this kind of identity reduction. ${ }^{29}$ In all cases, the result will be the identity of moral properties with complexes of acceptable natural properties. This kind of naturalism may not look very satisfying, and it is not the sort of naturalism most commonly proposed by naturalistic moral realists, ${ }^{30}$ who typically seek to identify moral properties with certain specific natural properties. There is nothing inconsistent about doing things in the way I have adumbrated here and at the same time thinking that a moral property is identical to a natural property or to some relatively small conjunction of natural properties. Supposing that good was identical to pleasurable, then all the good events would be pleasurable events in circumstances suitable for moral evaluation.

Unlike the worrying morons that might be feared to populate our universe, the kinds of properties suggested here are ontologically harmless. They do little violence to a thoroughly naturalistic, and possibly a thoroughly physicalistic, ontology. ${ }^{31}$ To see why, it will help to begin by thinking about how the question of naturalism in metaethics differs from some other prominent disputes about naturalism elsewhere in the philosophical literature. On reflection, it is perhaps no surprise that moral properties may be thought of as inoffensively naturalistic; the ontological demands of morality are light in comparison with those in areas such as mind and mathematics.

29 Moral properties may be able to satisfy the conditions for identity reduction, for example, set out in Chalmers and Jackson (2001).

30 See Railton (1986) and Smart (1961). Jackson (1998) elaborates some advantages of this view. Streumer (forthcoming) defends this style of naturalism from a number of possible objections.

31 At least the version of physicalism which requires a property's extension to contain only those objects that are either posited by our best present or future physics and complex objects (e. g. ordinary objects like tables and chairs) composed thereof. For some discussion see Heller (1990), Hirsch (2005) and Unger (1979). 
First consider mind. Traditional debates about non-naturalism in the philosophy of mind concern a kind of substance dualism. Cartesian accounts of mind, which hold that there is a separate mental substance commonly identified with souls, worry naturalistically inclined philosophers. The spectre of supernaturalism looms large in at least the historical debate about the mind/body problem. Substance dualism posits the existence of entities which are not countenanced by the sciences that naturalists or physicalists view as respectable arbiters of our ontology. For a Cartesian dualist, the property of being a conscious state would have in its extension souls or disembodied minds. Philosophers who accept naturalism outright or at least take it to be the default ontological view must regard Cartesian dualism as an ontological non-starter.

Moral realists of most stripes are not in the substance dualism business. ${ }^{32}$ Consider the archetypical non-naturalist realist, Moore. He thought that the main objects of moral evaluation were states of affairs, and that those were entirely natural. Thus, while he would have denied the identity of good with any natural property, he would have accepted that the extension of good was entirely natural. There is no spectre of supernaturalism looming even in a moral non-naturalist's ontology.

Turning to maths, a certain kind of strong Platonism about numbers holds that numbers are real objects. ${ }^{33}$ They are of course non-physical. We can treat this kind of number as a real abstractum. On this kind of Platonism, various mathematical properties have real abstracta in their extensions. The property of being the first successor integer to zero has in its extension the real abstractum one. Although numbers and other mathematical objects are made use of by the ontologically privileged sciences, they are not posited by such sciences and on many versions of natural-

32 Divine command theorists are an exception.

33 For a wide ranging discussion of Platonism in mathematics, see Balaguer (1998). 
ism and physicalism fall outside the realm of real objects. Platonism about numbers is not consistent with these forms of naturalism or physicalism.

Moral properties do not, or at least need not, have real abstracta in their extensions, not even for non-naturalists like Moore. In this sense, moral realism looks consistent with a number of forms of ontological naturalism and ontological physicalism.

Unlike mind and mathematics, in which substances and non-natural objects figure prominently, the general question about naturalism in metaethics is solely a question about properties. Whether moral properties can be thought of as interestingly non-natural depends on what properties turn out to be. It is easier to see why this is so by returning to the thesis of the global supervenience of the moral on the natural.

Global supervenience, combined with the assumption that abstracta are not bearers of moral properties, has the important implication that the extension of a moral property is natural. If properties are treated as functions from worlds to extensions, an intuitive way to divide up the natural properties from the non-natural ones is by looking at the contents of their extensions. Any property, the extension of which is entirely natural, will be counted as natural. Any property, the extension of which contains non-natural items (like numbers, souls, etc.), will be counted as nonnatural. This intuitive view shares a close affinity with one variety of physicalism, which holds that a property counts as physical just in case its truth conditions can be given (in principle) in the language of physics. The truth conditions for moral properties can be given as large disjunctive natural properties. ${ }^{34}$

Looking at things in this way, it becomes more difficult to understand why Mackie's argument from queerness has

34 Of course, one needs to be careful about the sense of 'can' invoked here. The truth conditions might be impossible for an individual to enumerate for reasons of time and ignorance, but it is not this sense of 'can' in which we are interested. 
seemed so forceful. It seems to me that the argument from queerness has the most force if one subscribes to a metaphysics with strongly reified properties. Although Mackie himself does not speak of moral particles attaching themselves to certain actions or state of affairs, Dworkin's morons illustrate nicely the degree to which the argument from queerness needs an ontologically weighty view of properties to gain any traction at all.

Perhaps the most charitable way to understand the ontological argument from queerness is to think that it picks up on what is supposed to be distinctively normative about normative properties, as brought out by the open question argument. The failure to close the question- $\mathrm{x}$ is $\mathrm{F}$, but is it good?- might be taken to pick up on some supposed feature of certain events or states of affairs that cannot be captured naturalistically. One way of putting this point is that moral properties cannot be reduced to or explained by properties like having a mass, a velocity, a spin, a quantity of energy, etc.

The direct failure to close the question about good is unlikely to tell against the large disjunction variety of reductive naturalism. There are two reasons for this. The first reason is that the naturalistic disjunctive predicate is likely to be too long to be uttered. This explanation is particularly friendly to Moore's substantial views about good. Being a holist, he would not have thought it likely that the extension of good was anything so simple as pleasure. Moorean extensions would be unutterably massive. The open question argument is consistent with the real definition of good's being very long, in addition to its being consistent with good's having no real definition. The second reason is that the open question argument may be reflecting only what we can know a priori. It can be understood as testing our concepts, rather than informing us about property identity (since the two can come apart). This response, at least partly driven by the developments in Saul Kripke's Naming and Necessity, seems persuasive to me. 
One might have the closely related worry that a naturalistic property will lack what is most important in the normative property to which it is putatively identical: namely, the normativity. The thought is that it is hard to see what could make any natural property be guiding. About this point, two observations are in order.

The first observation is that the losing the normativity objection is an objection that is driven in part by the view normative judgement internalism. Normative judgement internalism is the view that when one judges that $\mathrm{p}$ is good, one (on that basis) has a disposition to act in accordance with that judgement. Because normative judgement internalism is a view about judgement, what is important is that it is part of the concept of being good, or of something's being a reason, or of something's being wrong, etc., that it disposes one to act in the appropriate ways. The reasons we have for thinking that normative properties are normative in this sense would be consistent with its being the concepts that are inherently normative. It is difficult for me to see what is gained by insisting that good has the special property of being normative, as long as the concept of good is normative. I shall return to this point in the next section.

The second observation is that on an extensionalist account of properties, even second-order properties, like being normative in the sense used by the objection, will have natural extensions. Second order properties will have as their extensions sets of other extensions. So, even normativity in this sense will come out as natural. The same holds for magnetism, mutatis mutandis. I make this second observation in part to highlight the way in which it is a particular conception of properties, one that is not only realist, but extremely robust, that would be required to give the argument from queerness and related worries much bite. If one is not antecedently committed to such a robust view about properties, then the queerness objection may not have much force. The queer features of moral properties may not be 
there at all, and if they are, they, too, turn out only to have natural objects within their extensions.

\section{REFOCUSING ON CONCEPTS}

The temptation to imbue normative properties in general and moral properties in particular with special features of attraction and guidance may be the result of an unwarranted move from normative and moral concepts to normative and moral properties. If this is the case, then I believe that it is possible to reconcile many of Dworkin's trenchant observations about metaethical theorising in JFH with a more traditional view about metaethics. In this section I shall explain why this may be so. In the next and final section of this paper, I shall explain why Dworkin's challenge should be taken seriously by all metaethicists.

There is a plausible case to be made for the view that properties are co-intensional, but that concepts are hyper-intensional; that is, properties are unique up to necessary co-extension, whereas concepts are individuated more finely than their extensions. There are a number of motivations for thinking that concepts may be more finely individuated than properties. I wish to discuss just one of these motivations, and only in a sketchy manner. I think doing so will suffice for my purposes in this paper, but needless to say, this is only a consideration and not an argument.

Concepts play an important role in our thought and in our epistemology. Those things that can be known, inferred, and discovered through a priori investigation are epistemically available to us in part because various concepts, if grasped, are sufficiently informative just in virtue of having been grasped to provide us with information absent further empirical investigation. Concepts play a central role in helping us to organise our knowledge and beliefs about the world. Evaluative and normative concepts play the important role of helping us organise actions and states 
of affairs into the class of those that are to be sought out, avoided, respected, promoted, and so on.

Debates about, for example, normative judgement internalism ${ }^{35}$ are sometimes used to show that moral properties must be guiding, or normative, is the senses discussed in the previous section. Recognising that an action is right (has the property of being right) is sometimes claimed to be inherently motivating. From this, Mackie and others like him draw the inference that moral properties should themselves have the special property of being attractive or having guiding force.

Judgements, however, are psychological states. Assuming for the moment cognitivism about moral judgements, they are doxastic states that play particular roles in an agent's practical and theoretical deliberation. I have no interest here in arguing about moral judgement internalism per se, but it seems quite reasonable to me to think that its correctness or incorrectness hinges on what kind of role thoughts involving normative concepts play in an agent's psychology, and perhaps her practical and theoretical reasoning in particular. The correctness of NJI neither directly depends on nor directly implies anything about the nature of moral properties.

Another way of bringing out the point that concepts, rather than properties, have special normative relevance is to observe that there does not seem to be anything wrong in principle with metaethical views that are cognitivist and anti-realist. John Skorupski's irrealist cognitivsm and some of T. M. Scanlon's more recent work offers explanations of how normative thoughts and normative language can be truth functional and can play their distinctive roles in human thought without there being robust moral properties or robust moral facts. ${ }^{36}$ Even if one does not endorse an

35 Recall that normative judgement internalism is the view that judging that $\mathrm{x}$ is wrong in general motivates one to avoid doing $\mathrm{x}$, whereas judging that $\mathrm{x}$ is right in general motivates one to do $\mathrm{x}$.

36 See Scanlon (2009) and Skorupski (1999). 
irrealist moral metaphysics, one can take the point that the distinctively guiding and normative aspects of morality may have their home on the conceptual, rather than the metaphysical side.

If this is right, and if properties come cheaply, then one can take on board Dworkin's emphasis on understanding moral scepticism as an internal view without either denying the coherence of external scepticism or denying that moral claims have truth makers.

External scepticism remains coherent on the kind of metaphysical picture presented in the previous section, because there may be genuine moral properties or there may not be. Because moral properties come so cheaply and because they are not in tension with various plausible versions of naturalism and physicalism, it seems unlikely to me that any serious dispute about whether or not there are moral truths or falsehoods is likely to be settled by appealing to a non-gerrymandered metaphysics. Moral properties are fairly undemanding ontologically. While one could question aspects of the moral enterprise, including the truthaptness of moral claims, by resort to external scepticism, it seems like an unpromising route of inquiry. This point is reenforced when one considers the role of truth in metaethics.

Truth is a property of beliefs and sentences, what I have loosely lumped together under the heading 'claims'. On Dworkin's own view in JFH and on other views, ${ }^{37}$ truth makers are not required for truth-aptness. But, if there are real moral properties, then moral claims may well have truth makers. These truth makers are not epistemologically informative for the most part. The truth maker for the claim that $\mathrm{x}$ is wrong will just be that $\mathrm{x}$ is in the extension of the property of being wrong. Why it belongs in that extension or does not belong in that extension is a conceptual matter. Truth makers only determine that something has a particular truth value, not why it does. 


\section{CONCLusion}

Dworkin offers the following fictional conversation in JFH:

A: Abortion is morally wicked: we always in all circumstances have a categorical reason to prevent and condemn it.

B: On the contrary. In some circumstances abortion is morally required. Single teen-aged mothers with no resources have a categorical reason to abort.

$\mathrm{C}$ : You are both wrong. Abortion is never either morally required or morally forbidden. No one has a categorical reason either to have or not to have an abortion. It is always permissible and never mandatory, like cutting your fingernails.

D: You are all three wrong. Abortion is never either morally forbidden or morally required or morally permissible.

and comments:

...[D] might say, first, "Any proposition that assumes the existence of something that in fact does not exist is false. Or (as I sometimes think) neither true nor false. A, B and C are all assuming that moral duties exist. But no such thing exists, so none of them is making a true statement." D has fallen victim to morons -or rather the lack of them. If there are morons, and morons make moral claims true or false, then we might imagine that morons, like quarks, have colors. An act is forbidden only if there are red morons in the neighborhood, required only if there are green ones, and permissible only if there are yellow ones. So D declares that, because there are no morons at all, abortion is neither forbidden, nor required nor permissible. His assumption that there are no morons, he insists, is not itself a moral claim. It is a claim of physics or metaphysics... ${ }^{38}$ 
These passages strike at the heart of what Dwokin finds odd about external scepticism. D's answer, understood as an externally sceptical one, seems to singularly fail to address the question. Dworkin is right to criticise D, but I think we can understand D's mistake in a way slightly different to how Dworkin does.

$\mathrm{D}$ is free to claim, as he is in essence doing, that the entire conversation rests on a mistake. To say that abortion has any moral error at all is to accept wrongly that there are properties of moral error. It is true that the other conversants make this assumption, but so much the worse for them. One could make the conversation about whether abortion was permitted, forbidden, or required by fairies. One might reasonably reply 'None of the above, because there are no fairies'.

What is unsatisfactory about D's reply, as Dworkin suggests, is that he attempts to give a metaphysical answer. The truth-aptness of the various moral claims about abortion may or may not rest on whether there are genuine moral properties. This renders the response somewhat less impressive than it would be if there were a clear route from anti-realism to the view that moral claims are not truthapt. Because moral properties, at least on some reasonable views about properties, come cheaply, the metaphysical reply is only of interest if the demanding kind of picture of properties that Dworkin imputes to Mackie (an imputation with which I have some sympathy) is correct. In short, it seems unlikely that metaphysics will get us much of a grip on first order moral questions by casting doubt on the very sensibility of those questions.

Does that lead us as far as Dworkin would like us to go, to conclude that therefore moral scepticism must be internal? I think that it does not go quite that far, but it does suggest that the real action is at the level of concepts. External scepticism about morality fails to get at the interesting questions of whether we can have coherent concepts of good and bad, right and wrong, and if so, are they relative 
or absolute, and so on. In fact, it is these questions that Dworkin himself engages with directly. We can ask questions that are not strictly first order moral questions. The most interesting ones will be about concepts. Metaethicists who are not prepared to accept as revisionary a programme as Dworkin offers should still take the lesson from him that we should be thinking about moral concepts first and foremost and that worrying about metaphysics is unlikely to help us with answering moral questions, either metaethical or first order. Traditional metaethics can take on board much of what concerns Dworkin. His work in Justice for Hedgehogs helps improve metaethics for everyone.

\section{REFERENCES}

AYER, A. J., Language, Truth, and Logic, 2nd. ed., London, Gollancz, 1946.

BALL, S., "Reductionism in Ethics and Science: A Contemporary Look at G.E. Moore's Open-Question Argument", American Philosophical Quarterly, vol. 25, 1988, 197-213.

BAlaguer, Mark, 1998, Platonism and Anti-Platonism in Mathematics, Oxford, Oxford University Press, 1988.

BlackBuRn, S., Spreading the Word, Oxford, Oxford University Press, 1984.

BOYD, R., "How to Be a Moral Realist", in SAYRE-MCCORD, G. (ed.), Essays on Moral Realism, Ithaca, Cornell University Press, 1988, 181-228.

Chalmers, D. y JACKson, F., "Conceptual Analysis and Reductive Explanation", Philosophical Review, vol. 110, 2001, 315-361.

DwORKIN, R., Justice for Hedgehogs, Cambridge, Mass., Harvard University Press, 2011. 
Heller, M., The Ontology of Physical Objects: Four-Dimensional Hunks of Matter, Cambridge, Cambridge University Press, 1990.

HIRSCH, E., "Physical-Object Ontology, Verbal Disputes, and Common Sense", Philosophy and Phenomenological Research, vol. 70, 2005, 67-97.

JACKSON, F., From Metaphysics to Ethics: A Defence of Conceptual Analysis, United States of America, Oxford University Press, 2000.

MACKIE, J. L., "A Refutation of Morals", Australasian Journal of Philosophy, vol. 24, 1946, 77-90.

- Ethics: Inventing Right and Wrong, London, Penguin Books, 1977.

MCDOWELL, J., "Values and Secondary Qualities", in HONDERICH, T. (ed.) Morality and Objectivity, London, Routledge, 1985, 110-129.

Moore, G. E., Principia Ethica, Cambridge, Cambridge University Press, 1903.

RAILTON, P., "Moral Realism”, Philosophical Review, vol. 95, 1986, 163-207.

SCANLON, T. M. "Being Realistic: Locke Lecture 2: Metaphysical Objections", online MS, www.law.nyu.edu/ ecm_dlv4/...law.../ecm_pro_063552.pdf, 2009.

SKORUPSKI, J., "Irrealist Cognitivism", Ratio, vol. 112, 1999, 436-459.

Smart, J. J. C., An Outline of a System of Utilitarian Ethics, Melbourne, Melbourne University Press, 1961.

SoAmes, S., Philosophical Analysis in the Twentieth Century, Volume 1: The Dawn of Analysis, Princeton, Princeton University Press, 2005. 


\section{ANDREW REISNER}

StReumer, B., "Are Normative Properties Descriptive Properties?”, Philosophical Studies (forthcoming).

Stevenson, C. L., "The Emotive Meaning of Ethical Terms", Mind, vol. 46, 1937, 14-31.

Unger, P., "There Are no Ordinary Things", Synthese, vol. 41, 1979, 117-154. 